Extremophiles

October 2003; 7(5) : 361 - 370

http://dx.doi.org/10.1007/s00792-003-0329-4

(c) Springer-Verlag Tokyo Inc.

The original publication is available at http://www.springerlink.com
Archimer http://www.ifremer.fr/docelec/ Archive Institutionnelle de l'Ifremer

\title{
Desulfurobacterium crinifex sp. nov., a novel thermophilic, pinkish-streamer forming, chemolithoautotrophic bacterium isolated from a Juan de Fuca Ridge hydrothermal vent and amendment of the genus Desulfurobacterium
}

\author{
Karine Alain ${ }^{\mathrm{A} 1}$, Sophie Rolland ${ }^{\mathrm{A} 1}$, Philippe Crassous $^{\mathrm{A} 2}$, Françoise Lesongeur ${ }^{\mathrm{A} 1}$, Magali \\ Zbinden ${ }^{A 3}$, Christian le Gall ${ }^{A 2}$, Anne Godfroy ${ }^{A 1}$, Antoine Page ${ }^{A 1} A^{4}$, S. Kim Juniper ${ }^{A 4}$, Marie- \\ Anne Cambon-Bonavita ${ }^{A 1^{*}}$, Francis Duchiron ${ }^{A 5}$, Joël Querellou ${ }^{A 1}$
}

\footnotetext{
${ }^{\text {A1 }}$ Laboratoire de Microbiologie et de Biotechnologie des Extrêmophiles, Département de Valorisation des Produits IFREMER, Centre de Brest BP 7029280 Plouzané France

A2 Département Environnement Profond Plouzané France

A3 Laboratoire de Biologie Cellulaire et Moléculaire du Développement Paris France

${ }^{A 4}$ Geotop and Département des Sciences Biologiques Montréal Canada

A5 Laboratoire de Microbiologie Industrielle Reims France
}

*Marie.Anne.Cambon@ifremer.fr

\begin{abstract}
A novel thermophilic, chemolithoautotrophic bacterium, designated as NE1206 T, was isolated from a Juan de Fuca Ridge hydrothermal vent sample (tubes of the annelid polychaete Paralvinella sulfincola attached to small pieces of hydrothermal chimney). The cells were rod-shaped $(1.2-3.5 \times 0.4-0.7 \mu \mathrm{m})$, occurring as single motile rods or forming macroscopic aggregates visible as pinkish to brownish streamers. The new isolate was anaerobic. It grew between 50 and $70{ }^{\circ} \mathrm{C}$ (optimum $60-65{ }^{\circ} \mathrm{C}$; doubling time approximately $1 \mathrm{~h} 15 \mathrm{~min}$ at $60{ }^{\circ} \mathrm{C}$ ), between $\mathrm{pH} 5.0$ and 7.5 (optimum $\mathrm{pH}$ around 6.0-6.5) and at sea salts concentrations between 20 and $40 \mathrm{~g} \mathrm{I}-1$ (optimum $30 \mathrm{~g} \mathrm{I}$ -1). Cells grew chemolithoautotrophically in an $\mathrm{H} 2 / \mathrm{CO} 2$ atmosphere $(80 / 20, \mathrm{v} / \mathrm{v} ; 200 \mathrm{kPa})$. Molecular hydrogen was the sole electron donor used by the strain. Nitrate and elemental sulfur served as electron acceptors, yielding ammonia and hydrogen sulfide, respectively (nitrate reduction supported higher growth rates than sulfur reduction). The $G+C$ content of the genomic DNA was $36.7 \pm 0.8$ mol\%. Phylogenetic analyses of the 16S rRNA gene located the strain within the genus Desulfurobacterium. However, the novel isolate possesses physiological and biochemical characteristics that differ from the previously described species of this genus. We propose that the isolate represents a novel species, Desulfurobacterium crinifex sp. nov. The type strain is NE1206 T (DSM 15218 T, CIP 107649 T). An amendment of the genus Desulfurobacterium description is proposed, based on the phenotypic characteristics of the novel
\end{abstract}

Keywords: Cell networks, Deep-sea hydrothermal vent, Desulfurobacterium crinifex, Lithotroph, Nitrate-reducing, Thermophile 


\section{INTRODUCTION}

The deepest phylogenetically-branching bacterial phyla are, according to 16S rDNA phylogenetic analyses, the Aquificae and the Thermotogae. The phylum Aquificae includes the genera Aquifex (Huber et al., 1992), Thermocrinis (Huber et al., 1998), Hydrogenobacter (Kawasumi et al., 1984), Hydrogenobaculum (Stöhr et al., 2001), Hydrogenothermus (Stöhr et al., 2001) and the very recently described genus Persephonella (Götz et al., 2002). Cultivated representatives of this phylum have been isolated from marine and continental volcanic and geothermal heated springs (Reysenbach, 2001). Members of the Aquificae are thermophilic or hyperthermophilic rod-shaped microorganisms. Under some growth conditions and notably under a continuous water flow, many of them form long macroscopic filaments or aggregates forming coloured networks of cells (Eder et al., 2002). With the exception of the strict aerobic heterotroph Hydrogenobacter subterraneus (Takai et al., 2001), almost all Aquificae are strict chemolithoautotrophs able to grow by $\mathrm{O}_{2}$ (under microaerobic conditions) or $\mathrm{NO}_{3}{ }^{-}$reduction, using $\mathrm{CO}_{2}$ as a carbon source and $\mathrm{H}_{2}, \mathrm{~S}^{2-}, \mathrm{S}^{\circ}$ or $\mathrm{S}_{2} \mathrm{O}_{3}{ }^{2-}$ as an electron donor. Chemoorganoheterotrophic growth on simple organic molecules also occurs within the genus Thermocrinis (Huber et al., 1998). The phylum Thermotogae encompasses the genera Thermotoga (Huber et al., 1986), Petrotoga (Davey et al., 1993), Geotoga (Davey et al., 1993), Fervidobacterium (Patel et al., 1985), Thermosipho (Huber et al., 1989) and Marinitoga (Wery et al., 2001). Almost all cultivated members of this phylum have been isolated from extreme environments such as oil field brines or oil reservoirs, and from terrestrial or submarine volcanic areas (Alain et al., 2002a). Thermotogae are rod-shaped moderate thermophilic or hyperthermophilic bacteria surrounded by a characteristic sheath-like outer structure devoid of cytoplasm called the "toga". To date, all members are obligate anaerobes that derive energy from the fermentation of a broad range of organic compounds (carbohydrates, proteinaceous substrates or alcohols). In most cases, growth of these micro-organisms is enhanced by the addition of thiosulphate or other sulphur compounds (Ravot et al., 1995). In addition, the recently described methanol-fermenting Thermotoga lettingae is able to use ferric iron and anthraquinone-2,6-disulfonate as electron acceptors (Balk et al., 2002). Recently, two new species have been described belonging to two new genera that form a distinct 16S rRNA lineage between the order Aquificales and the order Thermotogales (L'Haridon et al., 1998; Huber et al., 2002). In the latest edition of 'Bergey’s Manual of Systematic Bacteriology’, the first species, Desulfurobacterium thermolithotrophum (L'Haridon et al., 1998) was placed in the phylum Aquificae but with the designation "genus incertae sedis" 
(L’Haridon \& Jeanthon, 2001). D. thermolithotrophum strain BSA ${ }^{\mathrm{T}}$, isolated from a Mid-Atlantic hydrothermal vent chimney, is a thermophilic strictly anaerobic chemolithoautotrophic bacterium growing by sulphur, thiosulphate or sulphite reduction with $\mathrm{H}_{2}$ as an electron donor. The second novel isolate, Thermovibrio ruber (Huber et al., 2002), isolated from sandy sediments of a hydrothermal vent off near Papua New Guinea, is a thermophilic, obligate anaerobic chemolithoautotrophic microorganism that reduces nitrate or sulphur in the presence of $\mathrm{H}_{2}$ as an electron donor and $\mathrm{CO}_{2}$ as a carbon source. The authors of both publications underline the fact that $D$. thermolithotrophum and T. ruber belong to the phylum Aquificae but may, presumably, represent a novel order when further isolates are described (L’Haridon et al., 1998; Huber et al., 2002).

In 2001, samples were collected from a deep-sea hydrothermal vent field on the Juan de Fuca Ridge, in the northeast Pacific ocean. In this paper, we report the isolation and describe the unique physiological and metabolic features of a novel isolate belonging to the genus Desulfurobacterium. In light of the phenotypic properties of this isolate, we describe it as the type strain of a new species and propose an amendment of the genus Desulfurobacterium.

\section{MATERIALS AND METHODS}

Collection of samples

Samples were collected at a depth of $1581 \mathrm{~m}$ from a sulphide edifice (T\&S edifice) in the CASM vent field $\left(130^{\circ} 01^{\prime} \mathrm{W}, 45^{\circ} 59^{\prime} \mathrm{N}\right)$ at Axial Volcano, on the Juan de Fuca Ridge, during the NeMO (New Millennium Observatory) 2001 expedition. Material collected by the remotely-operated vehicle (ROV) ROPOS consisted of small fragments of sulphide chimney and adhering tubes of the polychaete worm Paralvinella sulfincola, which colonizes the surface of actively venting sulphide edifices or chimneys. Once aboard ship, mucous tubes still attached to individual $P$. sulfincola were aseptically placed into sterile tubes containing sterile seawater (3\% [v/v] sea salts solution), $20 \%(\mathrm{v} / \mathrm{v})$ glycerol and frozen at $-20{ }^{\circ} \mathrm{C}$. Samples were transported frozen to the laboratory and thawed just before enrichment cultures. 


\section{Culture medium and conditions}

Isolate NE1206 ${ }^{\mathrm{T}}$ was enriched and grown with KA22 medium (Alain et al., 2002b), containing per litre: $30 \mathrm{~g}$ sea salts (Sigma), $2.54 \mathrm{~g} \mathrm{Mg}\left(\mathrm{NO}_{3}\right)_{2} \cdot 6 \mathrm{H}_{2} \mathrm{O}$ (Merck), 1 g NaHCO 3 , 1.95 g MES buffer (Sigma), 12 g elemental sulphur (Prolabo), $0.3 \mathrm{~g} \mathrm{KH}_{2} \mathrm{PO}_{4}$ (Sigma), $0.5 \mathrm{ml}$ vitamin mixture (Balch et al., 1979), $10 \mathrm{ml}$ trace element solution (Balch et al., 1979) and $1 \mathrm{mg}$ resazurin (Sigma). The $\mathrm{pH}$ was adjusted to 6.5 at room temperature, before autoclaving, and the medium was reduced by $0.5 \mathrm{~g}^{-1}$ sodium sulphide before inoculation. A mixture of $\mathrm{H}_{2} / \mathrm{CO}_{2}$ (80/20, vol./vol.; $200 \mathrm{kPa}$ ) was used as the gas phase. Unless indicated otherwise, cultures were incubated at $60{ }^{\circ} \mathrm{C}$ with shaking $(100 \mathrm{rpm})$.

Enrichment and purification procedures

Enrichment cultures were carried out anaerobically in liquid KA22 medium inoculated with solid fragments of Paralvinella sulfincola tubes, under an atmosphere of $\mathrm{H}_{2} / \mathrm{CO}_{2}$ (80/20, vol./vol.; $\left.200 \mathrm{kPa}\right)$. After 36 h incubation at $60{ }^{\circ} \mathrm{C}$, growth was observed by phase contrast microscopy. Positive cultures were subcultured and then purified using a dilution-to-extinction technique (Baross, 1995). Six serial dilutions to extinction were performed. A supplementary purification step was performed by streaking onto KA22 medium solidified with $0.8 \%(\mathrm{w} / \mathrm{v})$ Phytagel (Sigma) gelling agent. Plates were incubated in anaerobic jars at $60{ }^{\circ} \mathrm{C}$ for 10 days under a $\mathrm{H}_{2} / \mathrm{CO}_{2}$ (80/20, vol./vol.; $\left.200 \mathrm{kPa}\right)$ atmosphere.

Observation of the culture and quantification

Cells were observed under a light microscope equipped with a phase-contrast oil immersion objective $(\times 100$ magnification). Cells were counted by direct cell counting using a Thoma chamber (depth, $0.02 \mathrm{~mm}$ ).

Morphology

The Gram type was determined by use of the Ryu nonstaining KOH test (Ryu, 1940; Buck, 1982; Powers, 1995). The SpotTest ${ }^{\mathrm{TM}}$ flagella stain (Difco) was used for flagella detection. 
For scanning electron microscopy, cells were fixed with $10 \%$ formaldehyde (v/v) for one hour, placed on filters (0.22 $\mu \mathrm{m}$ pore size, Nucleopore) and dried over-night at room temperature. Macroscopic streamers were deposited directly onto filters and fixed over-night in a box under an atmosphere of formaldehyde. Samples were then coated with gold (SCD040, Balzers) and examined using a Philips XL 30-LaB6 scanning electron microscope.

Preparation of cells for ultrathin sectioning and transmission electron microscopy was as described elsewhere (Alain et al., 2002c). Ultra-thin sections (50 nm) were prepared on a Reichert-Jung Ultramicrotome. TEM observations were performed on a LEO 912 electron microscope.

Determination of growth parameters

To determine the optimum temperature, $\mathrm{pH}$ and sea salts concentration for growth, cells were grown in Hungate tubes (27 ml; Bellco) containing $5 \mathrm{ml} \mathrm{KA22}$ medium and $\mathrm{H}_{2} / \mathrm{CO}_{2}$ at a pressure of $200 \mathrm{kPa}$ in the headspace. All growth parameters were tested with $\mathrm{H}_{2}$ as the electron donor and $\mathrm{NO}_{3}{ }^{-}$( $\mathrm{S}^{\circ}$ was also present in the medium) as the electron acceptor. Experiments were performed in thermostatic aluminium heating blocks (Bioblock) monitored with temperature probes placed in control tubes. Parallel experiments were also performed in a thermostatic oven with shaking. To determine the effect of $\mathrm{pH}$ on the growth, KA22 medium was modified with the following 10 mM buffers (Sigma): for pH 3 and 4, no buffer; for pH 5, 5.5 and 6, MES (2-(N-morpholino)ethane sulfonic acid) buffer; for pH 6.5 and 7, PIPES (piperazine-N,N'-bis-(2-ethane sulfonic acid)) buffer; for pH 7.5 and 8, HEPES (N-(2-hydroxyethyl)-piperazine-N'-(2-ethane sulfonic acid)) buffer; for pH 8.5, AMPSO (3-(1,1-dimethyl-2-hydroxyethyl)-amino-2-hydroxypropane sulfonic acid) buffer. Sodium sulphide was added in the anaerobic chamber and, if necessary, the $\mathrm{pH}$ was adjusted with $0.1 \mathrm{M} \mathrm{HCl}$ or $0.1 \mathrm{M} \mathrm{NaOH}$. To determine the effect of sea salts concentration on the growth, KA22 medium was prepared with sea salts concentrations ranging from 0 to $70 \mathrm{~g} \mathrm{l}^{-1}$. For all salts concentrations, cells were incubated at the optimal temperature and $\mathrm{pH}$ for growth. The effects of temperature, $\mathrm{pH}$ and salinity were determined by measuring maximum growth rates calculated by use of linear regression analyses from six to seven points along the logarithmic growth curves in the portion of the curve where the slope was maximal. All growth experiments were carried out in triplicate. 
Physiological and biochemical characteristics

The ability of isolate $\mathrm{NE} 1206^{\mathrm{T}}$ to use various electron donors was investigated. For this experiment, the following electron donors were added to a minimal medium (modified KA22 medium without $\mathrm{S}^{\circ}$ but with $4 \mathrm{~g} \mathrm{l}^{-1}$ $\mathrm{MgSO}_{4} \cdot 7 \mathrm{H}_{2} \mathrm{O}$ to ensure an adequate sulphur source): formate (10 mM), acetate $(10 \mathrm{mM})$, propionate (10 mM), methanol $(0.5 \% \mathrm{v} / \mathrm{v})$, yeast extract $\left(2 \mathrm{~g} \mathrm{l}^{-1}\right), \mathrm{S}^{\circ}\left(12 \mathrm{~g} \mathrm{l}^{-1}\right), \mathrm{S}_{2} \mathrm{O}_{3}{ }^{2-}(10 \mathrm{mM})$ and $\mathrm{H}_{2} \mathrm{~S}(10 \mathrm{mM})$. These compounds were tested under anaerobic conditions with a $\mathrm{N}_{2} / \mathrm{CO}_{2}$ gas phase (80/20, vol./vol.; $\left.200 \mathrm{kPa}\right)$ with $\mathrm{NO}_{3}{ }^{-}$as the electron acceptor. $\mathrm{H}_{2}$ was also tested under anaerobic conditions as the sole electron donor $\left(\mathrm{H}_{2} / \mathrm{CO}_{2}, 80 / 20\right.$ vol./vol., $200 \mathrm{kPa}$ ). The following electron donors were also tested under microaerophilic conditions under an atmosphere of $\mathrm{N}_{2} / \mathrm{CO}_{2} / \mathrm{O}_{2}$ (80/17/3, vol./vol.; $\left.200 \mathrm{kPa}\right)\left(\mathrm{O}_{2}\right.$ percentages were measured by gas chromatography before inoculation): $\mathrm{Fe}^{2+}(10 \mathrm{mM}), \mathrm{S}^{\circ}\left(12 \mathrm{~g} \mathrm{l}^{-1}\right), \mathrm{S}_{2} \mathrm{O}_{3}{ }^{2-}(10 \mathrm{mM}), \mathrm{H}_{2} \mathrm{~S}(10 \mathrm{mM})$ and $\mathrm{H}_{2}\left(\mathrm{H}_{2} / \mathrm{CO}_{2} / \mathrm{O}_{2}, 80 / 17 / 3\right.$ vol./vol.; $200 \mathrm{kPa})$.

The ability of the new isolate to grow in the presence of different electron acceptors was tested on a modified KA22 medium (prepared without $\mathrm{Mg}\left(\mathrm{NO}_{3}\right)_{2}$ or sulphur but supplemented with $1 \mathrm{~g} \mathrm{l}^{-1} \mathrm{NH}_{4} \mathrm{Cl}$ to ensure an adequate nitrogen source): Sulphate was tested at $20 \mathrm{mM}$ on this modified sulphate-free medium. After the demonstration that the strain does not use sulphate as a terminal electron acceptor, the other electron acceptors were tested in the same modified KA22 medium supplemented by $4 \mathrm{~g} \mathrm{l}^{-1} \mathrm{MgSO}_{4} \cdot 7 \mathrm{H}_{2} \mathrm{O}$ to ensure a supplemental sulphur source. Elemental sulphur and L-cystine were tested at $12 \mathrm{~g} \mathrm{l}^{-1}$, polysulphides at $10 \mathrm{mM}$ (Blumentals et al., 1990), nitrite at $1 \mathrm{mM}, \mathrm{O}_{2}$ at concentrations ranging from 1 to $20 \%$, and thiosulphate, ferric iron and nitrate were tested at $20 \mathrm{mM}$. The headspace gas was $\mathrm{H}_{2} / \mathrm{CO}_{2}(80 / 20$, vol./vol.; $200 \mathrm{kPa}) . \mathrm{O}_{2}$ was also tested as a terminal electron acceptor (at concentrations ranging from 1 to $20 \%$ ) with $\mathrm{S}^{\circ}\left(12 \mathrm{~g} \mathrm{l}^{-1}\right)$ or $\mathrm{S}_{2} \mathrm{O}_{3}{ }^{2-}(10 \mathrm{mM})$ as the electron donor; in experiments where the headspace gas was $\mathrm{N}_{2} / \mathrm{CO}_{2}$ (80/20, vol./vol.; $\left.200 \mathrm{kPa}\right)$.

The ability of strain $\mathrm{NE} 206^{\mathrm{T}}$ to utilise different carbon sources was investigated by adding the following compounds to the KA22 medium prepared without $\mathrm{NaHCO}_{3}$ : formate $(10 \mathrm{mM})$, acetate $(10 \mathrm{mM})$, propionate (10 $\mathrm{mM})$, lactate $(0.5 \% \mathrm{v} / \mathrm{v})$, methanol $(0.5 \% \mathrm{v} / \mathrm{v})$, yeast extract $\left(2 \mathrm{~g} \mathrm{l}^{-1}\right)$, tryptone $\left(2 \mathrm{~g} \mathrm{l}^{-1}\right)$, peptone $\left(2 \mathrm{~g} \mathrm{l^{-1 }}\right), \mathrm{D}(+)-$ glucose $\left(2 \mathrm{~g} \mathrm{l}^{-1}\right)$, maltose $\left(2 \mathrm{~g} \mathrm{l}^{-1}\right)$, starch $\left(2 \mathrm{~g} \mathrm{l}^{-1}\right)$ and $\mathrm{CO}_{2}(20 \%)$. These experiments were performed under a $\mathrm{H}_{2}$ (100\%, $200 \mathrm{kPa})$ gas phase.

The effect of different growth factors was also tested. In separate experiments the KA22 medium was amended with complex organic substrates (yeast extract, peptone and tryptone added at $0.1 \% \mathrm{v} / \mathrm{v}$ ), organic acids (formate added at $0.5 \% \mathrm{v} / \mathrm{v}$, and acetate and propionate added at $0.1 \% \mathrm{v} / \mathrm{v})$, carbohydrates $(\mathrm{D}(+)$-glucose, $\mathrm{D}(+)$-galactose 
and maltose tested at $0.1 \% \mathrm{v} / \mathrm{v})$ and selenite-tungstate solution $\left(1 \mathrm{ml} \mathrm{l}^{-1}\right.$ of a stock solution: $6 \mathrm{mg} \mathrm{l}^{-1}$ $\left.\mathrm{Na}_{2} \mathrm{SeO}_{3} .5 \mathrm{H}_{2} \mathrm{O} ; 0.8 \mathrm{mg} \mathrm{l}^{-1} \mathrm{Na}_{2} \mathrm{WO}_{4} .2 \mathrm{H}_{2} \mathrm{O} ; 0.4 \mathrm{~g} \mathrm{l}^{-1} \mathrm{NaOH}\right)$.

All these tests were performed in triplicate in serum vials. Positive cultures were transferred at least twice on the same substrate combination to confirm growth. Growth was determined by direct cell counts in a Thoma chamber (depth $0.02 \mathrm{~mm}$ ) with a phase-contrast microscope.

Cytochrome oxidase activity was tested using the "oxidase “ kit (Remel), based on the reaction of N, Ndimethyl-1,4-phenylene diamine and alpha-naphtol, where the presence of oxidase activity is confirmed by a dark blue coloration.

Analyses of metabolic products and analytical techniques

$\mathrm{H}_{2} \mathrm{~S}$ formation was detected by the addition of $500 \mu \mathrm{l}$ of $50 \mathrm{mM} \mathrm{HCl}-5 \mathrm{mM} \mathrm{CuSO}_{4}$ to $0.2 \mathrm{ml}$ of the culture. A brown precipitate demonstrated the presence of $\mathrm{H}_{2} \mathrm{~S} . \mathrm{H}_{2} \mathrm{~S}$ concentrations were measured spectrometrically at 670 $\mathrm{nm} 1 \mathrm{~h}$ after addition of $0.1 \mathrm{ml}$ of a $100 \mathrm{mM} \mathrm{FeCl}_{3}$ solution and $0.1 \mathrm{ml}$ of a $19 \mathrm{mM} \mathrm{N}$, N-dimethyl-pphenylenediamine dihydrochloride to $10 \mathrm{ml}$ of culture, by comparison to an $\mathrm{H}_{2} \mathrm{~S}$ calibration curve.

Ammonium / ammonia concentrations were determined by use of an ammonia detection kit (Fa. Boehringer Mannheim/R-biopharm, Darmstadt, Germany) according to the manufacturer's instructions. This test was carried out spectrometrically after addition of NADH, 2-oxoglutarate, and glutamate-dehydrogenase to the samples yielding glutamate and NAD. Quantitative nitrate determination was performed by use of a nitrate detection kit (Fa. Boehringer Mannheim/R-biopharm, Darmstadt, Germany) following the manufacturer’s recommendations. This was carried out spectrometrically after addition of NADPH and nitrate reductase to the sample leading to nitrate reduction. The amount of NADPH oxidised during the reaction is stoichiometric to the amount of nitrate. For nitrate and ammonia determinations, cells were grown at $60^{\circ} \mathrm{C}$ on $\mathrm{KA} 22$ medium prepared without sulphur and resazurin ( $\mathrm{pH}$ 6.0, $30 \mathrm{~g} \mathrm{l}^{-1}$ sea salts, atmosphere of $\mathrm{H}_{2} / \mathrm{CO}_{2}$ ). For these experiments, samples were deproteinized with 5-sulfosalicylic acid, then degassed to eliminate carbon dioxide before determinations were performed. Nitrite was determined quantitatively using a colorimetric nitrite test kit (chemical method: sulfanilamide) (HI 3873; Hanna Instruments, France).

Gas percentages within gas atmosphere of vials were determined using an MTI micro-gas chromatograph equipped with a thermal conductivity detector. A molecular sieve with argon as the carrier gas and a temperature 
of $30{ }^{\circ} \mathrm{C}$ were used to detect $\mathrm{O}_{2}, \mathrm{H}_{2}$ and $\mathrm{N}_{2} . \mathrm{CO}_{2}$ was determined using a Poraplot $\mathrm{U}$ column, at $100{ }^{\circ} \mathrm{C}$, with helium as the carrier gas. The analysed gas phases were pumped from the culture vials directly and without gas contamination, by the suction pump of the MTI system.

DNA extraction and purification

Genomic DNA was extracted as described by Wery et al. (2001). The concentration and purity of the genomic DNA obtained were estimated by use of a GenQuant II spectrophotometer (Pharmacia) at 260, 280 and $320 \mathrm{~nm}$. The quality of the extraction was checked on a $0.8 \%(\mathrm{w} / \mathrm{v})$ agarose gel containing $0.5 \mu \mathrm{g}$ ethidium bromide $\mathrm{ml}^{-1}$.

DNA base composition and phylogenetic analysis

The $\mathrm{G}+\mathrm{C}$ content of the genomic DNA was determined from the melting point according to Marmur \& Doty (1962), as described elsewhere (Alain et al., 2002b). A calibration curve was constructed by use of ultrapure DNA from Escherichia coli Strain B (50\% G+C), Clostridium perfringens (26.5\% G+C) and calf thymus (42\% $\mathrm{G}+\mathrm{C}$ ) as standards (Sigma).

The 16S rDNA was selectively amplified from purified genomic DNA by PCR with oligonucleotide primers designed to anneal to conserved positions in the 3' and 5' regions of the 16S rRNA genes. The forward primer was SAdir (5'-AGAGTTTGATCATGGCTCAGA-3') corresponding to positions 8-28 in the Escherichia coli 16S rRNA and the reverse primer was S17rev (5'-GTTACCTTGTTACGACTT-3'), corresponding, 1493-1509. The initial denaturation step consisted of heating the reaction mixture to $94{ }^{\circ} \mathrm{C}$ for $3 \mathrm{~min}$. This was followed by 30 cycles as follows: denaturation at $94{ }^{\circ} \mathrm{C}$ for $1 \mathrm{~min}$, annealing at $49{ }^{\circ} \mathrm{C}$ for $1 \mathrm{~min} 30 \mathrm{~s}$ and extension at $72{ }^{\circ} \mathrm{C}$ for 2 min. A final extension step was carried out at $72{ }^{\circ} \mathrm{C}$ for $6 \mathrm{~min}$. The PCR products were analysed on $0.8 \%$ (w/v) agarose TAE-gels (0.04 M Tris-acetate, $0.001 \mathrm{M}$ EDTA), containing $0.8 \mu \mathrm{g}$ ethidium bromide $\mathrm{ml}^{-1}$ and recorded with a Fluor-S multiImager (Bio-Rad).

The 16S rDNA gene PCR product was bidirectionnally sequenced by Genome Express S.A. (Grenoble, France) with an automatic DNA analysis system (Applied Biosystems). The following primers, chosen to generate an overlapping set of sequences, were used for sequencing: SAdir, S17rev, 533F (5’TGBCAGCMGCCGCGGTAA-3’), 517R (5’-ACCGCGGCKGCTGGC-3’), 690R (5’-TCTACGCATTTCACC- 
3') and 1100R (5'-AGGGTTGCGCTCGTTG-3'). One thousand five hundred and twenty one positions of the $16 \mathrm{~S}$ rDNA were determined. To check for potential polymorphisms in the 16S rDNA genes and to confirm the direct sequencing results, PCR products were cloned into the PCR2.1 vector of the TOPO-TA cloning kit (Invitrogen). Ten independent 16S rDNA clone genes were sequenced.

The 16S rDNA sequence of the strain $\mathrm{NE}^{2} 206^{\mathrm{T}}$ was compared to the sequences of representative members of the phylum Aquificae and clones from hydrothermal vents or hot springs. The CLUSTALW method with weighted residues was used to align the sequences and to calculate similarity levels (Thompson et al., 1994). Alignment was manually refined by use of the multiple sequence alignment editor SEAVIEW and phylogenetic reconstruction was produced by use of PHYLO_WIN (Galtier et al., 1996) with the settings: Jukes-Cantor distance matrix, and successively the neighbor-joining (Saitou \& Nei, 1987) and maximum likelihood (Felsentein, 1981) methods. 1243 nucleotides were included in the phylogenetic analysis. Bootstrap values were determined according to Felsentein (1985). Marinitoga piezophila KA3 ${ }^{\mathrm{T}}$ (AF326121) was used as outgroup. Using the CLUSTALW method with weighted residues, similarity matrices were constructed on 1399 nucleotides of a subset of Aquificales sequences unequivocally aligned.

The 16S rDNA gene sequence of strain NE1206 ${ }^{\mathrm{T}}$ has been deposited in the EMBL database under the accession number AJ507320.

\section{RESULTS}

Enrichment, isolation and morphology

In order to enrich for thermophilic chemolithoautotrophic microorganisms, KA22 medium was inoculated with intact, small Paralvinella sulfincola tubes (cleaned of their inner content) attached to small fragments of hydrothermal chimney rocks. After 36 hours incubation, growth was observed at $60{ }^{\circ} \mathrm{C}$, under an $\mathrm{H}_{2} / \mathrm{CO}_{2}$ gas phase. The enriched culture consisted of dense populations of rod-shaped, motile cells. After 10 days incubation of plates under an $\mathrm{H}_{2} / \mathrm{CO}_{2}$ atmosphere at $60{ }^{\circ} \mathrm{C}$, pinkish colonies $1-2 \mathrm{~mm}$ in diameter were observed. One isolate, referenced as strain NE1206 ${ }^{\mathrm{T}}\left(\mathrm{DSM} 15218^{\mathrm{T}}\right.$, CIP $107649^{\mathrm{T}}$ ) was completely characterised. 
Phase-contrast microscopy indicated that cells of isolate $\mathrm{NE} 1206^{\mathrm{T}}$ were motile, straight to slightly curved rods of 0.9-3.5 $\mu \mathrm{m}$ long and 0.4-0.7 $\mu \mathrm{m}$ wide. When cultivated with shaking under anaerobic conditions, cells were slightly longer. Polar flagella were observed (Fig. 1a). As observed during scanning electron micrography analyses (Fig. 1b), cells divided by constriction. They were Gram-negative (Fig. 1c) and formed balloons during the late stationary phase of growth. Very frequently and systematically when growth occurred into nonreduced media, cells formed aggregates that arranged in macroscopic pinkish to brownish branched streamers. The total length of these pinkish cell networks, in vials, was sometimes up to $8 \mathrm{~cm}$ for a diameter that varied from the diameter of a hair to $2 \mathrm{~mm}$ diameter in vials. The microbial architecture of these unusual macroscopic structures was highly conserved from one streamer formed in vitro to another (Fig. 1d). This architecture was maintained by a polymeric matrix whose chemical composition and function are under characterisation.

Fig. 1. (a, b) Scanning electron micrographs of strain NE1206 ${ }^{\mathrm{T}}$ in the mid-exponential phase of growth, showing (a) polar flagella (b) division by constriction. Bar $=1 \mu \mathrm{m}$. (c) Transmission electron micrograph of ultrathin section of strain NE1206 ${ }^{\mathrm{T}}$ showing a Gram-negative cell envelope, with from inside to outside a cytoplasmic membrane (CM), a thin peptidoglycan layer (PG), an outer membrane (OM) and an S-layer (S). (d) Scanning electron micrograph of a macroscopic visible filament produced by cells of strain NE1206 ${ }^{\mathrm{T}}$ in culture vials (KA22 medium, $\mathrm{H}_{2} / \mathrm{CO}_{2}$ atmosphere, $60^{\circ} \mathrm{C}$ ), Bar $=500 \mu \mathrm{m}$.
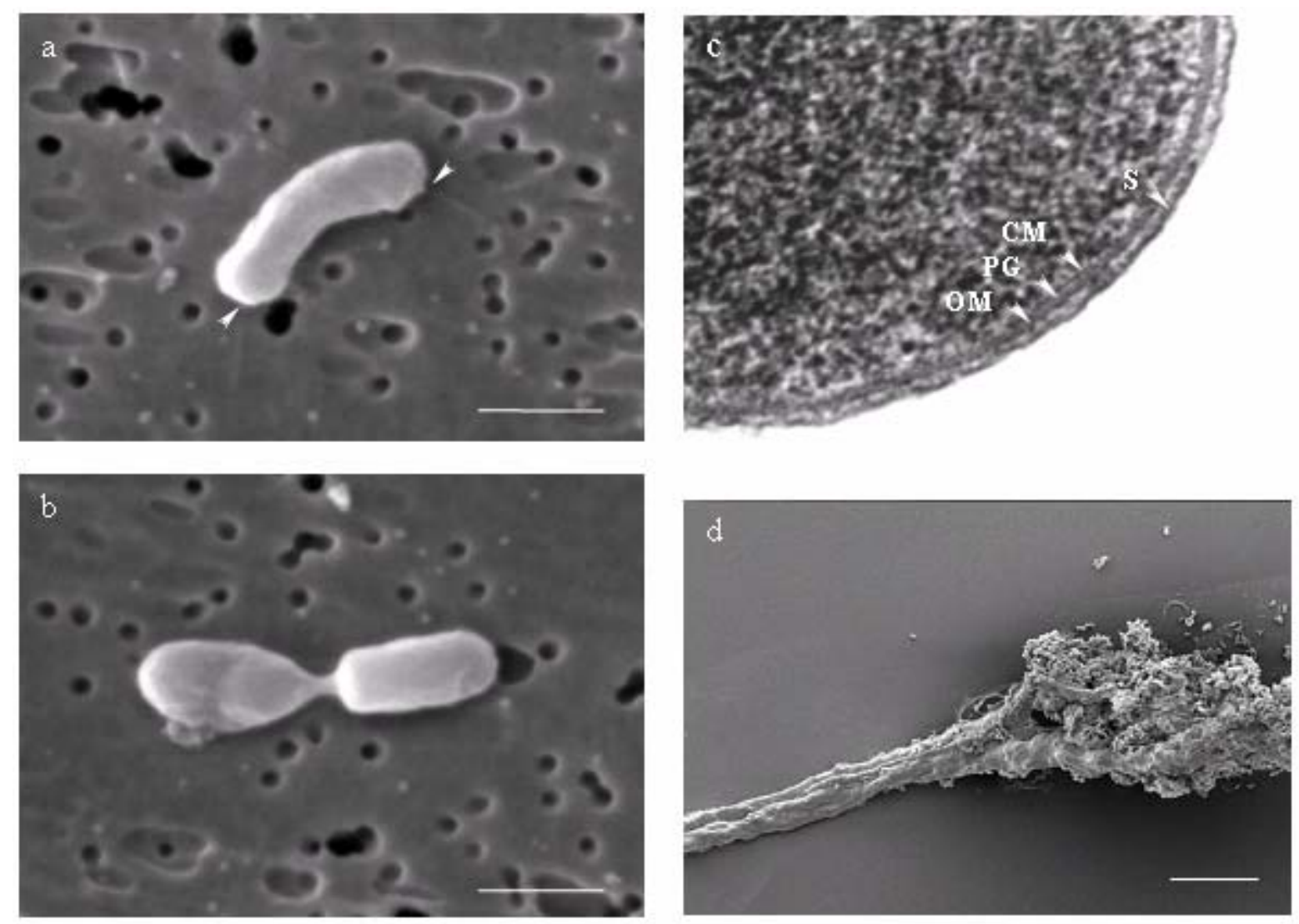
Growth parameters

The novel isolate $\mathrm{NE} 1206^{\mathrm{T}}$ grew between 50 and $70{ }^{\circ} \mathrm{C}$ with an optimum around $60-65{ }^{\circ} \mathrm{C}$. Growth did not occur at 45 or $75{ }^{\circ} \mathrm{C}$ (Fig. 2). The strain grew at sea salts concentrations between 20 and $40 \mathrm{~g} \mathrm{l}^{-1}$. The optimum sea salts concentration for growth was $30 \mathrm{~g} \mathrm{l}^{-1}$. Growth of the isolate was optimal around $\mathrm{pH}$ 6.0-6.5, although growth was observed at pH 5.0 and 7.5. Under optimal growth conditions (at $60{ }^{\circ} \mathrm{C}$ with shaking, $\mathrm{pH} 6.5,30 \mathrm{~g} \mathrm{l}{ }^{-}$ ${ }^{1}$ sea salts, with $\mathrm{H}_{2}$ as electron donor, $\mathrm{CO}_{2}$ as carbon source and $\mathrm{NO}_{3}{ }^{-}$as terminal electron acceptor) the doubling time was around 1 h 15 minutes.

Fig. 2. Effect of temperature on the maximum growth rate ( $\mu$ max) of strain $N E 1206^{\mathrm{T}}$. The cells were grown under agitation with $\mathrm{H}_{2}$ as electron donor, $\mathrm{CO}_{2}$ as carbon source and $\mathrm{NO}_{3}{ }^{-}$as terminal electron acceptor (at $\mathrm{pH}$ 6.5 and with $30 \mathrm{~g}$ sea salts $\mathrm{l}^{-1}$ ). The experiment was performed in triplicate. Maximum growth rates were calculated by performing linear regression analysis of the part of the logarithmic growth curves where the slope was maximal.

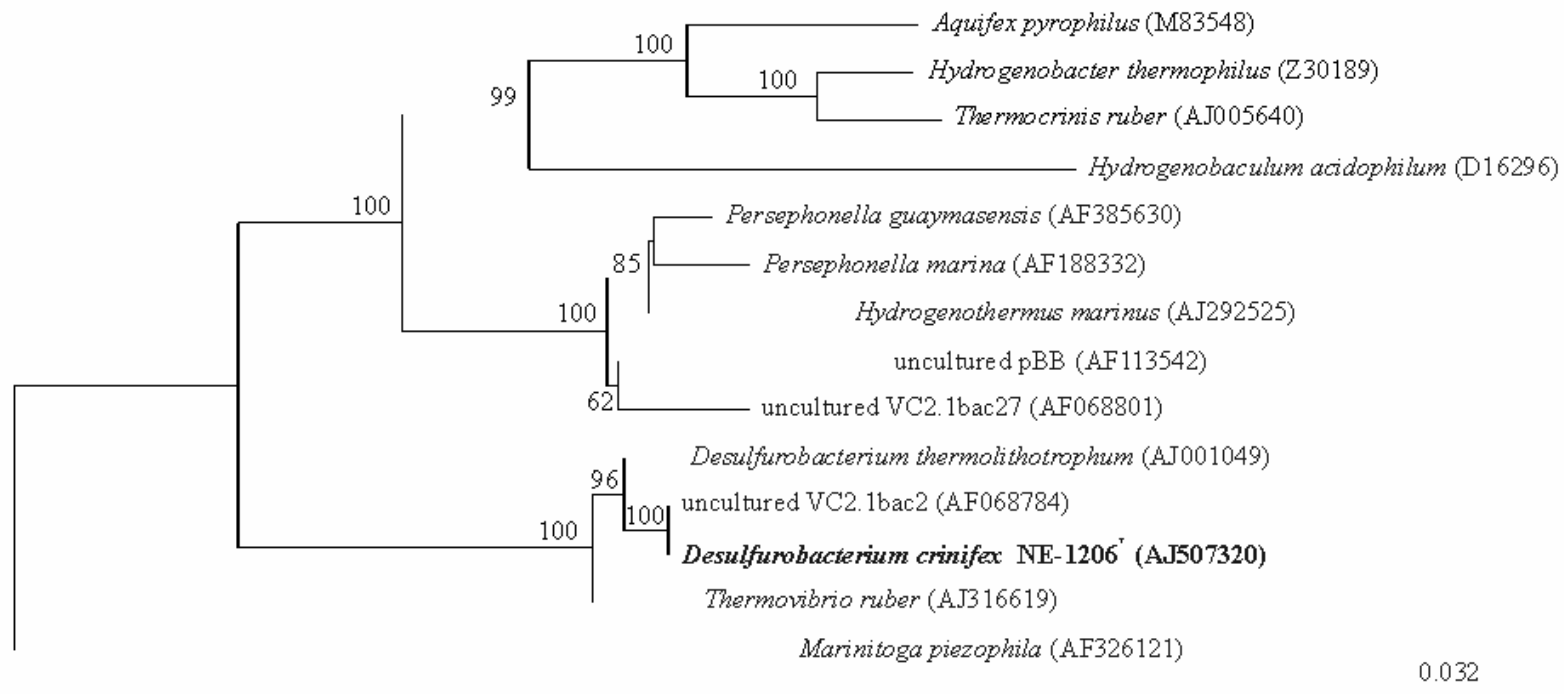

Growth characteristics

Strain NE1206 ${ }^{\mathrm{T}}$ was an anaerobic, cytochrome oxidase negative, hydrogen-oxidising, thermophilic bacterium. Tests for growth requirements highlighted the obligate chemolithoautotrophic character of the novel isolate. Growth was possible by reduction of nitrates or elemental sulphur, using molecular hydrogen as electron donor 
and carbon dioxide as carbon source (Table 1). The shortest generation times were obtained by nitrate-reduction. Ammonia was produced from nitrate reduction (Fig. 3). Nitrite could not be detected in the culture medium after growth by nitrate reduction. When nitrate was not present in the culture medium, $\mathrm{H}_{2} \mathrm{~S}$ was produced as a result of sulphur reduction. Final $\mathrm{H}_{2} \mathrm{~S}$ concentrations of 4.0 to $14.6 \mathrm{mmol} \mathrm{l}^{-1}$ were measured. The novel isolate was unable to grow organotrophically on the complex substrates or small organic molecules tested. On the other hand, the strain was found to tolerate low oxygen concentrations but was demonstrated to not reduce it. It could be grown on nonreduced KA22 medium (up to oxygen concentrations of 3\%) but exclusively without shaking or under a relatively gentle one (100-120 rpm). Under these conditions, a pinkish polymer was regularly produced. Moreover, final end products of anaerobic respiration $\left(\mathrm{H}_{2} \mathrm{~S}\right.$ if $\mathrm{S}^{\circ}$ was the electron acceptor or ammonia if that was nitrate) were detected in these nonreduced media. When shaken at high velocity (250 rpm), nonreduced media did not allow growth of the novel isolate (while reduced ones allowed it). Under this micro-oxygenation of the medium homogenised by a strong shaking, cellular lysis was observed only after 2 days incubation at 60 ${ }^{\circ} \mathrm{C}$. Furthermore, the novel isolate was unable to grow with oxygen (microaerophilic conditions with 1 to $20 \%$ $\mathrm{O}_{2}$ were tested) as the sole terminal electron acceptor when cultivated at $60{ }^{\circ} \mathrm{C}$ and at $250 \mathrm{rpm}$. All these results together demonstrate that the strain is able to tolerate oxygen but does not reduce it.

Fig. 3. Nitrate consumption (O) and ammonium / ammonia formation ( $\mathbf{\square}$ ) during growth ( $\Delta$ ) of strain $\mathrm{NE}$ $1206^{\mathrm{T}}$. This experiment was performed on a modified KA22 medium prepared without $\mathrm{S}^{\circ}$ and resazurin. Cultures were grown at $60{ }^{\circ} \mathrm{C}$, $\mathrm{pH} 6.0$, with $30 \mathrm{~g} \mathrm{l}^{-1}$ sea salts under an $\mathrm{H}_{2} / \mathrm{CO}_{2}$ atmosphere (80/20, vol./vol.; 200 $\mathrm{kPa}$ ).

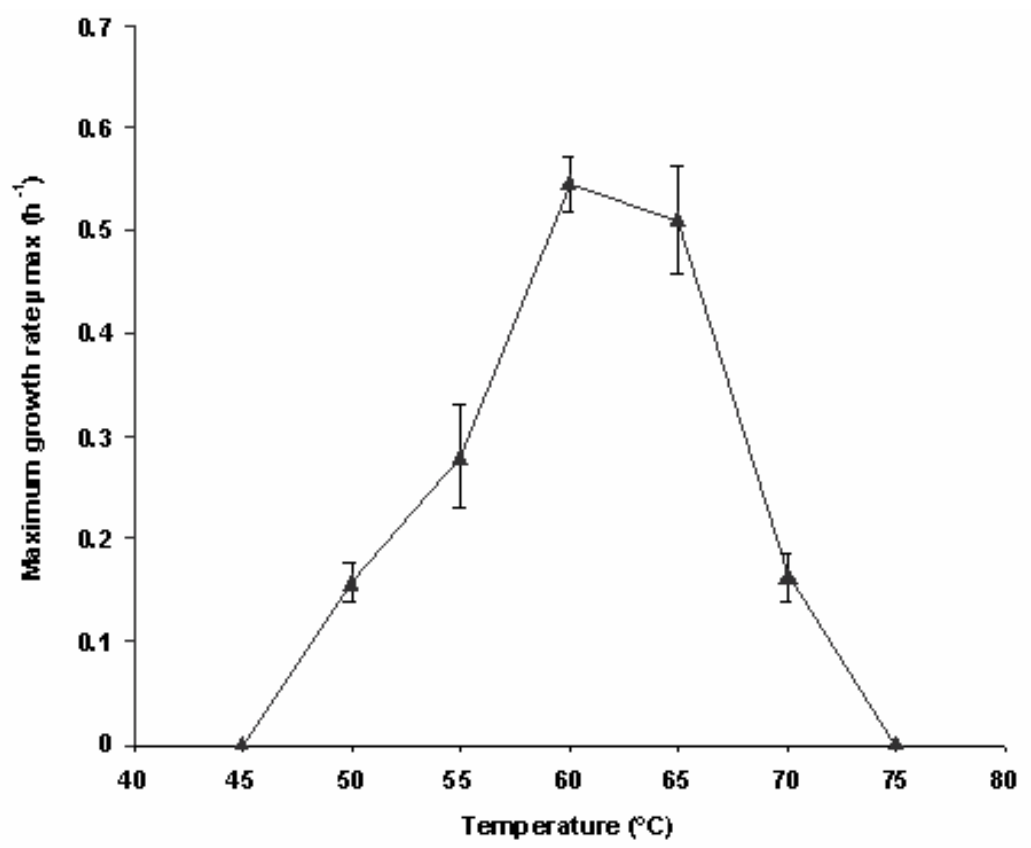


Table 1. Comparison of metabolic characteristics of Desulfurobacterium crinifex and Desulfurobacterium thermolithotrophum.

\begin{tabular}{|c|c|c|c|c|}
\hline Electron donor & Electron acceptor & Carbon source & D. thermolithotrophum * & D. crinifex \\
\hline $\mathrm{H}_{2}$ & $\mathrm{NO}_{3}^{-}$ & $\mathrm{CO}_{2}$ & - & $+\S$ \\
\hline $\mathrm{H}_{2}$ & $\mathrm{~S}^{\circ}$ & $\mathrm{CO}_{2}$ & $+\S$ & + \\
\hline $\mathrm{H}_{2} \mathrm{~S}$ & $\mathrm{O}_{2}(3 \%)$ & $\mathrm{CO}_{2}$ & ND & - \\
\hline $\mathrm{H}_{2} \mathrm{~S}$ & $\mathrm{NO}_{3}^{-}$ & $\mathrm{CO}_{2}$ & ND & - \\
\hline $\mathrm{Fe}^{2+}$ & $\mathrm{O}_{2}(3 \%)$ & $\mathrm{CO}_{2}$ & ND & - \\
\hline $\mathrm{S}_{2} \mathrm{O}_{3}{ }^{2-}$ & $\mathrm{NO}_{3}^{-}$ & $\mathrm{CO}_{2}$ & ND & - \\
\hline $\mathrm{S}_{2} \mathrm{O}_{3}{ }^{2-}$ & $\mathrm{O}_{2}$ (1 to $\left.20 \%\right)$ & $\mathrm{CO}_{2}$ & ND & - \\
\hline $\mathrm{S}^{\circ}$ & $\mathrm{O}_{2}$ (1 to $\left.20 \%\right)$ & $\mathrm{CO}_{2}$ & ND & - \\
\hline $\mathrm{S}^{\circ}$ & $\mathrm{NO}_{3}^{-}$ & $\mathrm{CO}_{2}$ & ND & - \\
\hline Formate & $\mathrm{NO}_{3}{ }^{-} / \mathrm{S}^{\circ}$ & $\mathrm{CO}_{2}$ & - & - \\
\hline methanol & $\mathrm{NO}_{3}{ }^{-} / \mathrm{S}^{\circ}$ & $\mathrm{CO}_{2}$ & - & - \\
\hline acetate & $\mathrm{NO}_{3}{ }^{-} / \mathrm{S}^{\circ}$ & $\mathrm{CO}_{2}$ & - & - \\
\hline propionate & $\mathrm{NO}_{3}{ }^{-} / \mathrm{S}^{\circ}$ & $\mathrm{CO}_{2}$ & ND & - \\
\hline yeast extract & $\mathrm{NO}_{3}{ }^{-} / \mathrm{S}^{\circ}$ & $\mathrm{CO}_{2}$ & - & - \\
\hline $\mathrm{H}_{2}$ & $\mathrm{NO}_{3}{ }^{-} / \mathrm{S}^{\circ}$ & glucose & ND & - \\
\hline $\mathrm{H}_{2}$ & $\mathrm{NO}_{3}{ }^{-} / \mathrm{S}^{\circ}$ & starch & ND & - \\
\hline $\mathrm{H}_{2}$ & $\mathrm{NO}_{3}{ }^{-} / \mathrm{S}^{\circ}$ & maltose & ND & - \\
\hline $\mathrm{H}_{2}$ & $\mathrm{NO}_{3}^{-} / \mathrm{S}^{\circ}$ & methanol & ND & - \\
\hline $\mathrm{H}_{2}$ & $\mathrm{NO}_{3}{ }^{-} / \mathrm{S}^{\circ}$ & peptone & ND & - \\
\hline $\mathrm{H}_{2}$ & $\mathrm{NO}_{3}{ }^{-} / \mathrm{S}^{\circ}$ & tryptone & ND & - \\
\hline $\mathrm{H}_{2}$ & $\mathrm{NO}_{3}{ }^{-} / \mathrm{S}^{\circ}$ & yeast extract & ND & - \\
\hline $\mathrm{H}_{2}$ & $\mathrm{NO}_{3}{ }^{-} / \mathrm{S}^{\circ}$ & $\mathrm{NaHCO}_{3}$ & ND & - \\
\hline $\mathrm{H}_{2}$ & $\mathrm{NO}_{3}{ }^{-} / \mathrm{S}^{\circ}$ & lactate & ND & - \\
\hline $\mathrm{H}_{2}$ & $\mathrm{NO}_{3}{ }^{-} / \mathrm{S}^{\circ}$ & formate & ND & - \\
\hline $\mathrm{H}_{2}$ & $\mathrm{NO}_{3}{ }^{-} / \mathrm{S}^{\circ}$ & acetate & ND & - \\
\hline $\mathrm{H}_{2}$ & $\mathrm{NO}_{3}{ }^{-} / \mathrm{S}^{\circ}$ & propionate & ND & - \\
\hline $\mathrm{H}_{2}$ & $\mathrm{SO}_{4}{ }^{2-}$ & $\mathrm{CO}_{2}$ & - & - \\
\hline $\mathrm{H}_{2}$ & $\mathrm{~S}_{2} \mathrm{O}_{3}{ }^{2-}$ & $\mathrm{CO}_{2}$ & + & - \\
\hline $\mathrm{H}_{2}$ & L-cystine & $\mathrm{CO}_{2}$ & - & - \\
\hline $\mathrm{H}_{2}$ & polysulphides & $\mathrm{CO}_{2}$ & + & - \\
\hline $\mathrm{H}_{2}$ & $\mathrm{SO}_{3}^{2-}$ & $\mathrm{CO}_{2}$ & + & - \\
\hline $\mathrm{H}_{2}$ & $\mathrm{NO}_{2}^{-}$ & $\mathrm{CO}_{2}$ & - & - \\
\hline $\mathrm{H}_{2}$ & $\mathrm{Fe}^{3+}$ & $\mathrm{CO}_{2}$ & ND & - \\
\hline $\mathrm{H}_{2}$ & $\mathrm{O}_{2}(1$ to $20 \%)$ & $\mathrm{CO}_{2}$ & ND & - \\
\hline
\end{tabular}

ND, not determined ; -, no gro wth ; +, growth ; § conditions for which higher growth rates were measured.

These data suggest that the new isolate is an obligate chemolithoautotrophic bacterium that produces energy by reducing elemental sulphur or nitrate using molecular hydrogen as an electron donor. Routinely, when cultivated under agitation with $\mathrm{H}_{2}$ as an electron donor, $\mathrm{NO}_{3}{ }^{-}$as an electron acceptor, $\mathrm{CO}_{2}$ as a carbon source (and under optimal temperature, $\mathrm{pH}$ and salinity), cell densities obtained were $5 \times 10^{7}-1 \times 10^{8}$ cells per $\mathrm{ml}$ in vials. Occasionally, final cell concentrations of $3 \times 10^{8}$ cells per ml were obtained. Under our experimental conditions, none of the electron acceptor/donor and carbon source combinations supported growth of strain NE1206 ${ }^{\mathrm{T}}$ (Table 1). When added individually to the KA22 medium and at the concentrations tested, selenite-tungstate solution, formate, galactose, maltose and tryptone had no effect on growth (Table 1). On the other hand, the addition of yeast extract, brain-heart infusion, peptone, acetate and propionate slightly lengthened the generation time of the strain. At the concentration tested, lactate had a complete inhibitory effect on growth. 
DNA base composition and phylogenetic position of the novel isolate

As determined by melting point analysis, the $\mathrm{G}+\mathrm{C}$ content of the genomic DNA of strain NE1206 ${ }^{\mathrm{T}}$ was $36.7 \pm$ 0.8 mol\%. Phylogenetic analyses of the almost complete sequence (1521 bp) of the 16S rDNA gene of strain NE1206 ${ }^{\mathrm{T}}$, using the neighbor-joining and maximum likelihood algorithms for tree reconstruction, located the strain in the deeply branching phylum Aquificae, within the genus Desulfurobacterium, in the domain Bacteria (Fig. 4). The phylogenetic position of the organism was determined by comparing the 16S rDNA sequence of strain NE1206 ${ }^{\mathrm{T}}$ to those of nine representative Aquificae species and to three $16 \mathrm{~S}$ rDNA sequences of uncultured Aquificae. In all calculations, its closest cultivated relative was Desulfurobacterium thermolithotrophum (L’Haridon et al., 1998), sharing 96\% 16S rDNA sequence similarity (value obtained by the CLUSTALW method on 1399 nucleotides of a subset of sequences of unequivocal alignment). It was followed by the recently described genus Thermovibrio ruber (95\%). The novel isolate was very closely related to the 16S rDNA sequence of the uncultured clone VC2.1bac2 (and to other sequences unmarked on the phylogenetic tree) from an Atlantic hydrothermal vent (Reysenbach et al., 2000). They shared 99\% 16S rDNA gene sequence similarity. The secondary structural feature of the 16S rRNA sequence, characterised by a CUC bulge and a single nucleotide bulge in the helix found at positions 198-219 (E. coli numbering), retrieved in the 16S rRNA sequence of Desulfurobacterium thermolithotrophum (L'Haridon et al., 1998) and proposed to be a signature of the Aquificales lineage (Reysenbach et al., 1994), was also shared by the novel isolate. 
Fig. 4. Phylogenetic position of strain $\mathrm{NE} 1206^{\mathrm{T}}$ within the phylum Aquificae. The alignment was performed with 16S rDNA sequences of representative Aquificae species and uncultured Aquificae from Atlantic hydrothermal vents and terrestrial hot springs. The Thermotogale Marinitoga piezophila was chosen as outgroup. Accession numbers are noted in brackets. The topology shown corresponds to an unrooted tree obtained by a neighbor-joining algorithm (Jukes and Cantor corrections) established using PHYLO_WIN. 1243 nucleotides were included in the phylogenetic analysis. Bootstrap values are displayed on their relative branches. Scale bar indicates $6.7 \mathrm{nt}$ substitutions per $100 \mathrm{nt}$. The positioning of the new isolate was confirmed by the maximum likelihood method.

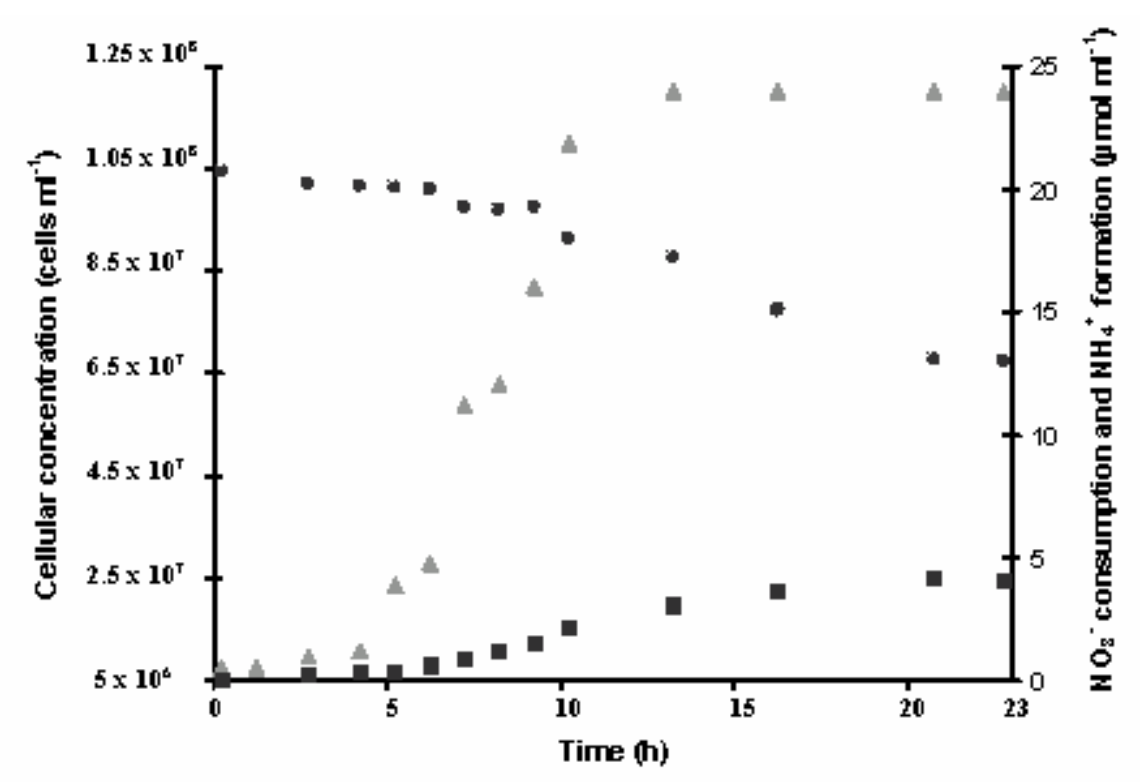

\section{DISCUSSION}

Phylogenetic analyses of the 16S rRNA sequence clearly indicated that the novel isolate belonged to a deepbranching lineage of Bacteria. This strain is an anaerobic, thermophilic bacterium growing autotrophically on $\mathrm{CO}_{2}$ by nitrate or sulphur reduction using hydrogen as an electron donor. On the basis of these characteristics, it resembles the recently described deeply-branching genus Thermovibrio (Huber, Diller et al. 2002). However, strain NE $1206^{\mathrm{T}}$ differs from Thermovibrio ruber (Huber, Diller et al. 2002) by its genotypic characteristics. The $\mathrm{G}+\mathrm{C}$ contents of the genomic DNA of both strains are almost 10\% different (46 mol\% for Thermovibrio ruber strain ED11/3LLK ${ }^{\mathrm{T}}$ against 36.7 mol\% for strain NE $1206^{\mathrm{T}}$ ). Moreover, based on the analysis of their $16 \mathrm{~S}$ rRNA sequences, they are phylogenetically distinct. The novel isolate is phylogenetically more closely related to the genus Desulfurobacterium. Strain NE $1206^{\mathrm{T}}$ shares some characteristics with the only described species, Desulfurobacterium thermolithotrophum (L'Haridon et al., 1998). Indeed, both strains grow 
chemolithoautotrophically using $\mathrm{CO}_{2}$ as a carbon source, $\mathrm{H}_{2}$ as an electron donor and $\mathrm{S}^{\circ}$ as an electron acceptor; their temperature, salinity and $\mathrm{pH}$ ranges for growth are relatively comparable; both strains are anaerobic; the $\mathrm{G}+\mathrm{C}$ content of the genomic DNA of $D$. thermolithotrophum and of the novel isolate are $35 \mathrm{~mol} \%$ and $36.7 \pm$ 0.8 mol\%, respectively ; cells stain Gram negative.

However, some characteristics distinguish both species; $D$. thermolithotrophum strain $\mathrm{BSA}^{\mathrm{T}}$ is capable of reducing thiosulphate and sulphite, whereas under our experimental conditions the new strain is not. The novel isolate shows a major metabolic difference from $D$. thermolithotrophum as a result of its ability to grow by nitrate reduction. The best growth rates of the strain were obtained chemolithoautotrophically, by anaerobic nitrate respiration, using $\mathrm{H}_{2}$ as an electron donor and $\mathrm{CO}_{2}$ as a carbon source.

Hydrothermal vent chimney structures result from the mixing of the hot hydrothermal fluid, rich in reduced chemical compounds, with the surrounding cold and oxygenated deep-sea water. Steep thermal and chemical gradients are established in the vicinity of the smokers. Both $\mathrm{CO}_{2}$ and $\mathrm{H}_{2}$, the exclusive carbon source and electron donor used by the strain in our experimental conditions, are abundant in hydrothermal fluids. Elemental sulphur are produced at vents as a result of chemical or biological oxidation of hydrogen sulphide, which is present in high concentration in the hydrothermal fluid. Finally, nitrates used by the strain as preferential electron acceptor are also available in the seawater into which the hydrothermal fluids are discharged. Unlike oxygen which is rapidly reduced by sulphide from the hydrothermal fluid, nitrate is a more stable electron acceptor that can persist in microniches in this ecosystem. Strain NE $1206^{\mathrm{T}}$, capable of growing chemolithoautotrophically either by sulphur reduction or by anaerobic nitrate reduction shows a metabolic plasticity by using several chemical species and gases available in its environment. Consequently, it has the potential to be an important primary producer within its ecological niche.

In addition to the metabolic characteristics that distinguish both strains, the ability of $D$. thermolithotrophum strain $\mathrm{BSA}^{\mathrm{T}}$ to form macroscopic coloured streamers in liquid culture has not been reported previously, to our knowledge. Polymer production was very frequently observed in cultures of the novel isolate, and occurred systematically when cells were submitted to low oxygen concentrations. Based on the principle that bacterial polymers are generally produced as direct and functional responses to selective pressures in the environment (Whitfield, 1988), this observation could suggest that oxygen would be an important environmental constraint for polymer secretion. This hypothesis has still to be corroborated, especially since polymer production was also often observed under anaerobic conditions. A thorough investigation of the architecture of the unusual cellular network built by the novel isolate and an analysis of the chemical composition of the polymer matrix embedding 
its cells is in progress. This may lead to physiological and ecological insights and to a better understanding of the population dynamic of the strain in vitro and in situ (Alain et al., in preparation).

Furthermore, the novel isolate tolerated oxygen but was unable to use it as a terminal electron acceptor. Growth under non-reductive conditions occurred only under relatively gentle shaking (100 - $120 \mathrm{rpm})$ but never at high velocity (250 rpm). As stated in the Results section, products of anaerobic respiration (ammonia or $\mathrm{H}_{2} \mathrm{~S}$ according to the electron acceptor provided in the medium) were detected in the culture media, suggesting the probable occurrence of local anaerobic microniches within the culture media. It is possible that the polymeric matrix, once produced by the cells in an anaerobic microniche, could protect them from oxygen while concurrently the $\mathrm{H}_{2} \mathrm{~S}$ they produced would contribute to reducing the culture medium.

Although Desulfurobacterium thermolithotrophum and the novel isolate were both isolated from hydrothermal samples (sulphide chimney sample for $D$. thermolithotrophum and a tube of the polychaete Paralvinella sulfincola mixed with sulphide chimney fragment for the novel isolate), they exhibit major phenotypic differences. They were isolated from geographically well-separated hydrothermal environments. The first strain was isolated from a Mid-Atlantic Ridge sample (L’Haridon et al., 1998) and the novel isolate from Juan de Fuca Pacific Ridge in the Pacific. Up to now, the occurrence of members of the genus Desulfurobacterium, detected either by culture or by molecular method, was restricted to hydrothermal chimneys of the Mid-Atlantic Ridge (Reysenbach et al., 2000). This study expands their geographical localisation to deep-sea hydrothermal vents of the northeast Pacific. Considerable further work would be required to determine whether the observed differences between $D$. thermolithotrophum and the novel isolate are just a biogeographical consequence or are a result of a microflora selection by the different chemical and mineralogical differences between the two environments. Replicate sampling under similar habitat conditions will be required before any biogeographical influences can be considered. Additionally, a thorough examination of the architecture and polymeric composition of the unusual macroscopic network built by cells of the novel isolate (and perhaps by other members of this genus) might give us clues to understand their physiological and ecological behaviour in their biotope.

On the basis of the 16S rRNA sequence distance, the morphologic and major metabolic differences between the novel isolate and Desulfurobacterium thermolithotrophum, we propose to assign strain $\mathrm{NE} 1206^{\mathrm{T}}$ as the type strain of a novel species for which we propose the name Desulfurobacterium crinifex (= which makes hair). 
Amendment of the genus Desulfurobacterium

The description of Desulfurobacterium is based on L'Haridon et al. (1998), plus the following characteristics: Anaerobic. Sulphur, thiosulphate, sulphite and nitrate can be reduced. Cells, in liquid culture may form macroscopic coloured cell masses encased in a polymeric matrix.

Description of Desulfurobacterium crinifex, sp. nov.

Desulfurobacterium crinifex sp. nov. (cri’ni.fex; L. masc. n. crinis, hair; L. suffix n. -fex, maker; N. L. nom n. crinifex, hair maker, to indicate the production of streamers by the organism). Cells are rod-shaped (0.9-3.5 length $\times$ 0.4-0.7 $\mu \mathrm{m}$ wide), motile with polar flagella and stain Gram-negative. Cells divide by constriction. Growth occurs between $50^{\circ} \mathrm{C}$ and $70{ }^{\circ} \mathrm{C}$ (optimum: 60-65 ${ }^{\circ} \mathrm{C}$ ), $\mathrm{pH} 5.0$ and 7.5 (optimum: 6.0-6.5), 20 and $40 \mathrm{~g}$ sea salts $\mathrm{l}^{-1}$ (optimum: 30 g sea salts $\mathrm{l}^{-1}$ ). Optimal doubling time around $1 \mathrm{~h} 15$ min.; mean cell yield comprised between $5 \times 10^{7}$ and $1 \times 10^{8}$ cells $\mathrm{ml}^{-1}$; maximum cell yield: $3 \times 10^{8}$ cells $\mathrm{ml}^{-1}$ in vials (with shaking). Anaerobic. Obligate chemolithoautotrophic. Hydrogen-oxidising. Reduces $\mathrm{NO}_{3}{ }^{-}$and $\mathrm{S}^{\circ} \cdot \mathrm{H}_{2} \mathrm{~S}$ is formed from $\mathrm{S}^{\circ}$ and ammonia is formed from $\mathrm{NO}_{3}{ }^{-} \mathrm{G}+\mathrm{C}$ content is $36.7 \pm 0.8 \mathrm{~mol} \%$. Isolated from a tube of the hydrothermal

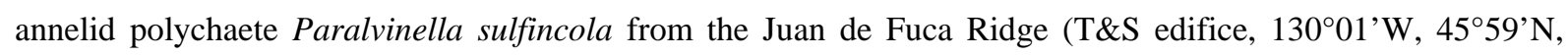

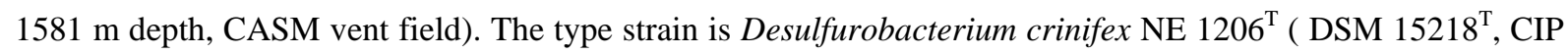
$107649^{\mathrm{T}}$ ). The EMBL accession number for the $16 \mathrm{~S}$ rDNA sequence for NE $1206^{\mathrm{T}}$ is AJ507320.

\section{ACKNOWLEDGEMENTS}

We thank Professor H. Trüper (University of Bonn, Germany) for correction of the etymology of the new species. We are grateful to Christian Jeanthon and Stéphane L’Haridon for stimulating and critical discussions. We acknowledge the officers and crew of the R/V Brown and the ROV Ropos operations team. We thank the 'Service de microscopie électronique', IFR de biologie intégrative, CNRS/Paris VI, for transmission electron microscopy.

This work was financially supported by Ifremer, Programme Dorsales, Région Bretagne and the Natural Sciences and Engineering Research Council of Canada. 


\section{REFERENCES}

Alain, K., Marteinsson, V.T., Miroshnichenko, M.L., Bonch-Osmolovskaya, E.A., Prieur, D. \& Birrien, J.-L. (2002a) Marinitoga piezophila sp. nov., a rod-shaped, thermo-piezophilic bacterium isolated under high hydrostatic pressure from a deep-sea hydrothermal vent. Int J Syst Evol Microbiol 52: 1331-1339.

Alain, K., Quérellou, J., Lesongeur, F., Pignet, P., Crassous, P., Raguénès, G., Cueff, V. and Cambon-Bonavita, M.A. (2002b) Caminibacter hydrogeniphilus, gen. nov., sp. nov., a novel thermophilic hydrogen-oxidising bacterium isolated from an East-Pacific rise hydrothermal vent. Int J Syst Evol Microbiol 52: 1317-1323.

Alain, K., Pignet, P., Zbinden, M., Quillevere, M., Duchiron, F., Donval, J.-P., Lesongeur, F., Raguenes, G., Crassous, P., Querellou, J., Cambon-Bonavita, M.-A. (2002c) Caminicella sporogenes gen. nov., sp. nov., a novel thermophilic spore-forming bacterium isolated from an East-Pacific Rise hydrothermal vent. Int J Syst Evol Microbiol 52: 1621-1628.

Balch, W. E., Fox, G. E., Magrum, L. J., Woese, C. R. \& Wolfe, R. S. (1979) Methanogens: reevaluation of a unique biological group. Microbiol Rev 43: 260-296.

Balk, M., Weijma, J. \& Stams, A.J.M. (2002) Thermotoga lettingae sp. nov., a novel thermophilic, methanoldegrading bacterium isolated from a thermophilic anaerobic reactor. Int J Syst Evol Microbiol 52: 1361-1368.

Baross, J. A. (1995) Isolation, growth and maintenance of hyperthermophiles. In Archaea: a Laboratory Manual. Thermophiles (ed. F. T. Robb \& A.R. Place. Cold Spring Harbor, N.Y. Cold Spring Harbor Laboratory) 15-23.

Blumentals, I. I., Itoh, M., Olson, G. J. \& Kelly, R. M. (1990) Role of polysulfides in reduction of elemental sulfur by the hyperthermophilic archaebacterium Pyrococcus furiosus. Appl Environ Microbiol 56: 1255-1262.

Buck, J. D. (1982) Nonstaining (KOH) method for determination of Gram reactions of marine bacteria. Appl Environ Microbiol 44: 992-993. 
Davey, M. E., Wood, W. A., Key, R., Nakamura, K. \& Stahl, D. A. (1993) Isolation of three species of Geotoga and Petrotoga: two new genera, representing a new lineage in the bacterial line of descent distantly related to the “Thermotogales”. System Appl Microbiol 16: 191-200.

Eder, W. \& Huber, R. (2002) New isolates and physiological properties of the Aquificales and description of Thermocrinis albus sp. nov.. Extremophiles 6: 309-318.

Felsentein, J. (1981) Evolutionary trees from DNA sequences: a maximum likelihood approach. J Mol Evol 17: 368-376

Felsentein, J. (1985) Confidence limits on phylogenies: an approach using the bootstrap. Evolution 30: 783-791.

Galtier, N., Gouy, M. \& Gautier, C. (1996) SEAVIEW and PHYLO_WIN: two graphic tools for sequence alignment and molecular phylogeny. Comput Appl Biosci 12: 543-548.

Götz, D., Banta, A., Beveridge, T.J., Rushdi, A.I., Simoneit, B.R.T. \& Reysenbach, A.-L. (2002) Persephonella marina gen. nov., sp. nov. and Persephonella guaymasensis sp. nov., two novel, thermophilic, hydrogenoxidizing microaerophiles from deep-sea hydrothermal vents. Int J Syst Evol Microbiol 52: 1349-1359.

Huber, R., Langworthy, T. A., König, H., Thomm, M., Woese, C. R., Sleytr, U. B. \& Stetter, K. O. (1986) Thermotoga maritima sp. nov. represents a new genus of unique extremely thermophilic eubacteria growing up to $90^{\circ} \mathrm{C}$. Arch Microbiol 144: 324-333.

Huber, R., Woese, C. R., Langworthy, T. A., Fricke, H. \& Stetter, K. O. (1989) Thermosipho africanus gen. nov., represents a new genus of thermophilic eubacteria within the “Thermotogales”. System Appl Microbiol 12: 32-37.

Huber, R., Wilharm, T., Huber, D., Trincone, A., Burggraf, S., Konig, H., Rachel, R., Rockinger, I., Fricke, H. \& Stetter, K.O. (1992) Aquifex pyrophilus gen. nov. sp. nov., represents a novel group of marine hyperthermophilic hydrogen-oxidizing bacteria. System Appl Microbiol 15: 340-351. 
Huber, R., Eder, W., Heldwein, S., Wanner, G., Huber, H., Rachel, R., \& Stetter, K.O. (1998) Thermocrinis ruber gen. nov. sp. nov., a pink-filament-forming hyperthermophilic bacterium isolated from Yellowstone National park. Appl Environ Microbiol 64: 3576-3583.

Huber H., Diller, S., Horn, C. \& Rachel, R. (2002) Thermovibrio ruber gen. nov., sp. nov., a novel extremely thermophilic, chemolithoautotrophic deeply branching bacterial nitrate-reducer. Int J Syst Evol Microbiol 52: 1859-1865.

Kawasumi, T., Igarashi, Y., Kodama, T. \& Minoda, Y. (1984) Hydrogenobacter thermophilus gen. nov., sp. nov., an extremely thermophilic, aerobic, hydrogen-oxidizing bacterium. Int J Syst Bact 34: 5-10.

L’Haridon, S., Cilia, V., Messner, P., Raguénès, G., Gambacorta, A., Sleytr, U.B., Prieur, D. \& Jeanthon, C. (1998) Desulfurobacterium thermolithotrophum gen. nov., sp. nov., a novel autotrophic, sulphur-reducing bacterium isolated from a deep-sea hydrothermal vent. Int J Syst Bact 48: 701-711.

L’Haridon, S. \& Jeanthon, C. (2001) Genus incertae sedis I. Desulfurobacterium. In Bergey’s manual of Systematic bacteriology. $2^{\text {nd }}$ edn. Vol. one, pp 359-367. Edited by G. m. Garrity. New York, Berlin, Heidelberg: Springer.

Marmur, J. \& Doty, P. (1962) Determination of the base composition of desoxyribonucleic acid from its thermal denaturation temperature. J Mol Biol 5: 109-118.

Patel, B. K. C., Morgan, H. W. \& Daniel, R. M. (1985) Fervidobacterium nodosum gen. nov. and spec. nov., a new chemoorganotrophic, caldoactive, anaerobic bacterium. Arch Microbiol 141: 63-69.

Powers, E. M. (1995) Efficacy of the Ryu nonstaining KOH technique for rapidly determining Gram reactions of food-borne and waterborne bacteria and yeasts. Appl Environ Microbiol 61: 3756-3758. 
Ravot, G., Ollivier, B., Magot, M., Patel, B. K. C., Crolet, J.-L., Fardeau, M.-L. \& Garcia, J.-L. (1995) Thiosulfate reduction, an important physiological feature shared by members of the order Thermotogales. Appl Environ Microbiol 61: 2053-2055.

Reysenbach, A. L., Longnecker, K. \& Kirshtein, J. (2000) Novel bacterial and archaeal lineages from an in situ growth chamber deployed at a Mid-Atlantic Ridge hydrothermal vent. Appl Environ Microbiol 66: 3798-3806.

Reysenbach, A.-L. (2001) Phylum BI. Aquificae phy. nov. In Bergey’s manual of Systematic bacteriology. $2^{\text {nd }}$ edn. Vol. one, pp 359-367. Edited by G. m. Garrity. New York, Berlin, Heidelberg: Springer.

Ryu, E (1940) A simple method of differentiation between Gram-positive and Gram-negative organisms without staining. Kitasato Arch Exp Med 17: 58-63.

Saitou, M. \& Nei, M. (1987) The neighbor-joining method: a new method for reconstructing phylogenetic trees. Mol Biol Evol 4: 406-425.

Stöhr, R., Waberski, A., Völker, H., Tindall, B.J. \& Thomm, M. (2001) Hydrogenothermus marinus gen. nov., sp. nov., a novel thermophilic hydrogen-oxidizing bacterium, recognition of Calderobacterium hydrogenophilum as a member of the genus Hydrogenobacter and proposal of the reclassification of Hydrogenobacter acidophilus as Hydrogenobaculum acidophilum gen. nov., comb. nov; in the phylum ‘Hydrogenobacter/aquifex’. Int J Syst Evol Microbiol 51: 1853-1862.

Takai, K., Komatsu, T. \& Horikoshi, K. (2001) Hydrogenobacter subterraneus sp. nov., an extremely thermophilic, heterotrophic bacterium unable to grow on hydrogen gas, from deep subsurface geothermal water. Int J Syst Evol Microbiol 51: 1425-1435.

Thompson, J. D., Higgins, D. G. \& Gibson, T. J. (1994) CLUSTAL W: improving the sensitivity of progressive multiple sequence alignment through sequence weighting, position-specific gap penalties and weight matrix choice. Nucleic Acids Res 22: 4673-4680. 
Wery, N., Lesongeur, F., Pignet, P., Derennes, V., Cambon-Bonavita, M.A., Godfroy, A. \& Barbier, G. (2001) Marinitoga camini gen. nov., sp. nov., a rod-shaped bacterium belonging to the order Thermotogales, isolated from a deep-sea hydrothermal vent. Int J Syst Evol Microbiol 51: 495-504.

Whitfield, C. (1988) Bacterial extracellular polysaccharides. Can J Microbiol 34: 415-420. 